\title{
Kennedy, Congress and Civil Rights
}

\author{
JOHN HART
}

President Kennedy's assassination in November $196_{3}$ was quickly followed by a wave of instant history, mainly produced by those who worked closely with him in the White House. Sorensen, Schlesinger and Salinger all published their memoirs in the mid-sixties, while O'Donnell and O'Brien followed suit in the early seventies. It was inevitable that their assessment of the Kennedy Presidency would be a favourable one and it was equally inevitable that it would generate a reaction from those who believed that the Kennedy myth needed to be destroyed. The instant history of the sixties has now given way to the instant revisionism of the seventies and John F. Kennedy is getting a distinctly unfavourable press. ${ }^{1}$ Leaving aside foreign affairs, it is Kennedy's handling of civil rights to which the revisionists are most antagonistic. Here the relationship between the President and Congress is brought sharply into focus. It is argued that Kennedy did not put before the legislature the wide-ranging and bold commitments on civil rights made during the election campaign; that his approach to the problem was tailored to suit the sensibilities of the southern Democrats in the House and Senate, and that he studiously avoided offering moral and political leadership to the country at large. Thus Henry Fairlie blames Kennedy for " procrastination and tokenism" "; Lewis Paper argues that Kennedy's handling of civil rights "did not speak well of his success as a public educator" 3 and Bruce Miroff, perhaps the most outspoken of all the critics, places Kennedy's

John Hart lectures in Political Science at The Australian National University, Canberra.

1 See, for example, Henry Fairlie, The Kenneay Promise: The Politics of Expectation (New York: Doubleday, 1973); Louise Fitzsimons, The Kennedy Doctrine (New York: Random House, 1972); Bruce Miroff, Pragmatic Illusions: The Presidential Politics of John F. Kennedy (New York: David McKay, 1976); Lewis J. Paper, The Promise and the Performance: The Leadership of John F. Kennedy (New York: Crown, 1975); Richard J. Walton, Cold War and Counter-Revolution: The Foreign Policy of John F. Kennedy (New York: Viking Press, 1972).

${ }^{2}$ Fairlie, pp. 250-51.

3 Paper, p. 243.

Amer. Stud. 13, 2, 165-178 Printed in Great Britain

$0021-8758 / 79 /$ BAAS-2001 $\$ 01.50$ (C) 1979 Cambridge University Press 
performance in the context of "pragmatic liberalism rooted in elite politics" - an approach which he unhesitatingly condemns. ${ }^{4}$

Conflict between Kennedy and Congress over domestic policy was manifested in a wide range of issues like tax-reform, medicare, aid-to-education, farm subsidies, minimum wages and government reorganization, but, undoubtedly, civil rights was the most important domestic issue of the period and it is understandable that it features so prominently in all the Kennedy literature. Yet the revisionist treatment of Kennedy's relations with Congress on civil rights matters does less than justice to the reality of the situation and needs some modification. Without wishing to share the conclusions drawn by Carl Brauer, in his otherwise excellent study, that Kennedy led America into its Second Reconstruction, ${ }^{5}$ there is a need to look again at three particular facets of the revisionist argument: the campaign commitments, the Presidential strategy on civil rights, and the concepts of Presidential leadership on which the critique is frequently based.

Kennedy's position on civil rights prior to his nomination in 1960 was a moderate one. In his quest for the Presidency he had made overtures to both southern Democrats and Negroes and, indeed, in the late 1950s, discovered that he had a credibility problem with the Negro leadership as a result of his moderation. Kennedy frequently found himself under attack from Clarence Mitchell and Roy Wilkins of the NAACP and, at one stage in the 1960 election campaign, even Martin Luther King spoke of the possibility of blacks voting for Nixon claiming that Nixon " had made a real impression on the Negro." " Martin Luther King's father, of course, had been an outspoken Nixon supporter until the famous Kennedy telephone call to Mrs. King while her husband was in a Georgia jail.

Kennedy's shift from a moderate to a more liberal position on civil rights after his nomination in 1960 was largely dictated by the content of the Democratic platform adopted at the convention and was not of his own choosing. The civil rights plank was the centrepiece of the platform and committed the party to virtually all of the proposals made by the civil rights advocates in Congress during the previous five years. The platform pronounced that " the time has come to assure equal access for all Americans to all areas of community life including voting booths, schoolrooms, jobs,

4 Miroff, Ch. 6.

5 See Carl M. Brauer, John F. Kennedy and the Second Reconstruction (New York: Columbia Univ. Press, 1977). I do not believe that the well-researched evidence presented by Brauer supports the conclusions he draws from it.

- Quoted in Brauer, p. $3 \mathbf{I}$. 
housing and public facilities." " These were precisely the areas of contention between the liberals and the conservatives in Congress, but the liberal position dominated in the platform committee and specific legislative commitments were made to eliminate poll taxes and literacy tests, ending discrimination in education, the establishment of a Fair Employment Practices Commission and an end to discrimination in federal housing allocations. ${ }^{8}$ The platform also promised legislation to provide the Attorney-General with powers to seek court injunctions against breaches of civil rights laws. This provision is frequently referred to as Title III and had been removed from both the 1957 and 1960 bills by the conservatives. The emphasis of the civil rights plank was firmly on legislation and it was implicitly a criticism of the inadequacy of previous legislation passed by Congress. It found its way into the 1960 platform, according to Sundquist, because the Democrats had departed from the established tradition of appointing non-ideological platform committee chairmen. ${ }^{\circ}$ Chester Bowles had been given the job by Paul Butler, the Democratic National Committee Chairman, and it has been suggested that Kennedy was not too pleased with the outcome of this decision. ${ }^{10}$

Kennedy's initial campaign utterances on civil rights were consistent with the platform promises, but, again, this was dictated by circumstances rather than choice. As the newly elected party leader, Kennedy could not be seen to oppose such an important section of the platform of the party he now led. He was also forced to defend the civil rights plank by a Republican manoeuvre during the short session of Congress following the party conventions. The Republicans had introduced a civil rights bill knowing it would not pass. It was principally designed to embarrass and divide the Democratic party, and, in order to minimize the damage, liberal Democrats in the Senate combined with the southerners to have it tabled. However, having maintained an appearance of unity, the liberals then had to reassert their civil rights credentials, and on I September, 24 Senators, including Kennedy, issued a statement which denounced Republican tactics and concluded with a promise that " ... we pledge action to obtain consideration of a civil rights bill by the Senate early next session that will implement the pledges of the Democratic platform." ${ }^{11}$ Kennedy could hardly refuse to

7 The Rights of Man, Report of the Committee on Resolutions and Platforms as adopted by the Democratic National Convention, 20 July Ig6o, p. 53 .

8 The best account of how the 1960 platform was put together and why the liberals came to be in such a commanding position is James L. Sundquist's Oral History Interview at the John F. Kennedy Library, pp. I-Io. Sundquist was then Secretary to the platform committee.

9 Sundquist, Oral History Interview, John F. Kennedy Library, p. Io.

10 See Theodore C. Sorensen, Kennedy (New York: Harper \& Row, 1965), p. 157.

11 See The Speeches of Senator John F. Kennedy, Presidentral Campaign of 1960, Final 
sign such an affirmation of the platform and, as his party's leader, was also expected to do something about it. He thus added a separate statement in which he said :

In order to implement this pledge and assure prompt action, I have asked Senator Clark and Congressman Celler to constitute a committee to prepare a comprehensive civil rights bill, embodying our platform commitments, for introduction at the beginning of the next session. We will seek the enactment of this bill early in that Congress. ${ }^{12}$

This statement, and a similar one made in Los Angeles nine days later, came back to haunt Kennedy throughout his Presidency. In Los Angeles he extended the commitment even further and told his audience that:

When our next President takes office in January, he must be prepared to move forward in the field of human rights in three general areas: as a legislative leader, as Chief Executive and as the center of moral power of the United States. ${ }^{13}$

Given Kennedy's attitude to civil rights legislation while he was President, one might assume that there is enough evidence here to support at least the charge that the candidate was misleading the public. Most of the revisionist writings do cite these two particular statements in support of their argument. But these remarks were made in the opening week of the election campaign and critics rarely look beyond those first two statements on civil rights. If they did so, they would discover a significant shift in Kennedy's position, marking a very real departure from the Democratic platform. After the Los Angeles speech, civil rights became far less prominent in Kennedy's campaign. He barely mentioned the issue throughout the rest of September - perhaps because he was campaigning mostly in non-urban areas - and a new approach began to emerge clearly at the beginning of October. When Kennedy faced a question and answer session in Minneapolis on I October one member of the audience asked him what legislation had he in preparation on the civil rights issue and his answer revealed a clear shift of emphasis from legislative action to the potential of executive action. He began:

I think I will say two or three things. First, there is a great deal that can be done by the executive branch without legislation. For example, the President could sign an Executive order ending discrimination in housing tomorrow. ${ }^{14}$

He then provided some examples of the types of action that could be undertaken by the executive branch in relation to contracts, voting rights and job

Report of the United States Senate Committee on Commerce, 87 th Congress Ist Session, Senate Report 994, Part I, p. 69.

12 Ibid., p. 70.

13 Ibid., p. I91.

14 Ibid., p. 432. 
discrimination, and concluded by saying, "the greater opportunity is in the executive branch without Congressional action." This idea was repeated when Kennedy appeared on NBC's " Meet the Press" on I6 October. He was asked a question about guaranteeing the right to vote and he stated that, in his view, the powers to guarantee voting rights were already there but had not been used effectively hitherto. He told Elie Abel of The Detroit News that:

the Executive has full power to provide the right to vote. I don't think there is any legal limitation now, any lack of weapons by the Attorney General or the President to compel the right to vote if a major effort is made. ${ }^{15}$

By mid-October the commitment to sweeping civil rights legislation was gone. Kennedy had begun to realize the practical and political problems of implementing the civil rights plank in the party platform and had changed his campaign statements accordingly. Even when he spoke to the National Conference on Constitutional Rights and American Freedom in New York on 12 October, he played down legislation and stressed again the potential of executive branch action. ${ }^{16}$ This also proved to be his last major campaign address on civil rights. Kennedy did refer to the position of Negroes thereafter, but he did so in the context of employment opportunities or access to education. He never again mentioned the civil rights bill.

The campaign set the tone for the Presidency. Civil rights issues were to be dealt with in a low-key manner without confronting the Congress if it could be helped. In Kennedy's first State of the Union message there was just one token sentence on the subject and no promise of any action whatsoever. ${ }^{17}$ Instead, the administration began to focus on what could be achieved by executive action inside the executive branch and, within two weeks of the inauguration, he had received a lengthy memorandum from Fred Dutton of the White House staff outlining a series of specific proposals for executive rather than Congressional action. ${ }^{18}$

This strategy was apparent during the election campaign. Kennedy had made it quite clear by November that he did not believe that the introduction of a major civil rights bill was the most productive line of action and that he would seek a more pragmatic or realistic approach. His earlier commitments to civil rights legislation were out of keeping with his general

15 See The Joint Appearances of Senator John F. Kennedy and Vice President Richard M. Nixon, Presidential Campaign of 1960, Final Report of the United States Senate Committee on Commerce, 87th Congress Ist Session, Senate Report 994, Part III, p. 25 I.

16 The Speeches of Senator John F. Kennedy, pp. 575-78.

17 See Public Papers of the Presidents, 196I (Washington D.C.: Government Printing Office, 1962), p. 20.

18 Memorandum to the President from Fred Dutton, 9 Feb. 196r, John F. Kennedy Papers (White House Central Files HU Box 358), John F. Kennedy Library. 
views and made in unusual circumstances. Even though the rhetoric of the campaign may have masked the substance, Kennedy's stand on civil rights should be evident to those who profess to be writing history today and it is misleading to judge Kennedy on the failure to implement a commitment which had been considerably modified before the voters had elected him in November. If historians are to make judgments by comparing the "promises" and the "performance" then, in so far as civil rights is concerned, they must begin to look at what was done by executive action rather than what was not done by Presidential legislative leadership. ${ }^{19}$

\section{II}

The Congressional problems that Kennedy had anticipated during the campaign became a reality as soon as the results of the election were available. He had beaten Nixon by a margin of 0.17 per cent of the popular vote and the usual problems of voting irregularities in Illinois continued to throw doubt on the legitimacy of his victory. There was no way in which the result of the 1960 Presidential election could be used to justify a mandate for any proposed policy initiative, least of all on civil rights. This was further underlined by the outcome of the Congressional elections. Although the Democrats had retained control of both chambers, they suffered an abnormal loss of seats. The Republicans took two seats from the Democrats in the Senate and had a net gain of twenty-one seats in the House. Sorensen claimed that every one of the displaced House Democrats was a Kennedy progressive and that this undoubtedly reflected on the incoming President. ${ }^{20}$ Worse still was Kennedy's performance when compared to that of the Democratic Congressional candidates. In only seven out of the thirty-four Senate contests did the Democratic candidate get a smaller percentage of the two-party vote than Kennedy, and each of those seven lost. In other words, every Democratic Senator elected in Ig60 ran ahead of Kennedy in his own state. Similarly, in only seven out of the fifty states did Kennedy receive a higher share of the two-party vote than did the Democratic candidates for House seats. The reality of the 1960 Congressional elections was that very few members of Congress were dependent on John Kennedy for their electoral success. To complete the picture one must also look at the position of the southern Democrats whose power was left intact after the election. The Democratic party majority in the House was eighty-seven, but

${ }^{19}$ The Kennedy administration's record in this regard is well documented by Brauer, and by Victor Navasky, Kennedy Justice (New York: Atheneum, 197I). See also Arthur M. Schlesinger Jr., Robert F. Kennedy and His Times (London: Andre Deutsch, 1978), Chaps. 14-16.

20 Sorensen, p. 339 . 
this was almost entirely negated by the ninety-nine Democrats from the eleven southern states. In the Senate, two-thirds of the standing committees were in the hands of southerners including the Judiciary Committee which was firmly under the control of James Eastland of Mississippi. The position was similar in the House where the South had eleven of the nineteen chairmanships.

This, then, was the context of Kennedy's relations with Congress on civil rights policy. During the election campaign he had switched his strategy from legislative to executive action and appears to have done this on the basis of two assumptions he had made about possible Congressional reaction to legislative proposals. His first assumption was that a civil rights bill would not be passed by the 87th Congress and the second assumption was that a civil rights initiative by the President would adversely affect other items of legislation in the New Frontier programme - items that may have been of more direct benefit to the blacks than simply the legal end to discrimination. ${ }^{21}$ The extent to which Kennedy was justified in acting upon these assumptions should be considered in any judgment that is to be made about his Presidential leadership.

The first assumption was easy to justify. One simply needs to look at those civil rights matters that did come before Congress during the years of the Kennedy Presidency. There was an immediate indication of difficulty when the Senate Banking and Currency Committee considered the nomination of Robert Weaver, a Negro, as Housing and Home Finance Administrator. The Committee approved the nomination, but considerable opposition was expressed by southerners when the vote came before the Senate itself. ${ }^{22}$ Robertson and Eastland strongly objected to Weaver's views on racially integrated housing and this episode was to serve as a prelude to the more successful opposition one year later to the establishment of a housing and urban affairs department after Kennedy had named Weaver as his intended nominee to head the new organization. There was also trouble in $196 \mathrm{I}$ over nominations to the Civil Rights Commission. Eastland and Ellender led a floor fight against Spottswood Robinson and managed to marshal seventeen votes against his nomination. More serious difficulties occurred over the extension of the life of the Commission. The conservative coalition brought its influence to bear to defeat several proposals and eventually the Senate settled for a token two-year extension supported by the two floor leaders, Mansfield and Dirksen, but almost every negative vote was from a southern

\footnotetext{
21 See Theodore C. Sorensen, The Kennedy Legacy (New York: Macmillan, 1969), p. 220 and Lawrence O'Brien, No Final Victories: $A$ Life in Politics from John F. Kennedy to Watergate (New York: Doubleday, 1974), p. I44.

22 See Congressional Record, 9 Feb. 1961, p. 1965.
} 
Democrat. ${ }^{23}$ Another problem in the Senate was that the Judiciary Committee had blocked every civil rights bill presented to it during the first session of the 87 th Congress. Humphrey, Douglas, Clark and Javits had all submitted bills which Eastland simply refused to consider.

The best indication of the hopelessness of Kennedy's position vis-à-vis passage of a civil rights bill was the attempt early in 1962 to float a trial balloon in the form of a literacy test bill. The essence of the bill, sponsored by Senator Mansfield, was that a sixth grade education be the only literacy test for voters in Presidential and Congressional elections. When the Judiciary Committee refused to take any action on the bill, Mansfield brought it back to the floor of the Senate by attaching it as an amendment to a minor bill already passed by the House. Inevitably, the southern Democrats responded with a filibuster and two cloture petitions were filed. The first attempt on 9 May was defeated 53-43 with $3^{\circ}$ Democrats supporting the filibuster. The second cloture vote one week later was defeated 52-42 and was a clear indication of the hopeless task facing Kennedy. Not only was Mansfield twenty-one votes short of a two-thirds majority on the second cloture attempt, but he was also six votes short of a simple majority on both occasions. The abolition of literacy tests was just one aspect of the civil rights plank in the Democratic platform, but this episode proved that Kennedy and the Congressional leadership were in no position to shut off a filibuster on any civil rights bill. It marked the end of any further attempts during that Congress.

The I 962 mid-term elections did not substantially alter the composition of Congress, nor the nature of the problem facing Kennedy. An attempt to change Rule XXII was soundly defeated in the Senate at the beginning of the 88th Congress and the eventual submission of a civil rights bill in June 1963 was the inevitable and unavoidable consequence of the events in Alabama and Mississippi rather than any admission that the situation in Congress had changed. The Senate Judiciary Committee sat on that bill too and it was only some deft political manoeuvering by Kennedy and Lawrence O'Brien that started the bill moving in the House two days before the President's death. ${ }^{24}$ With hindsight, therefore, Kennedy was more than justified in making the assumption he did about the chances of civil rights legislation getting anywhere at all in the Congress.

The second assumption, that the introduction of a civil rights bill would

23 Ibid., 30 Aug. 196r, p. 17526.

24 O'Brien persuaded Kennedy to ask Minority Leader Charles Halleck for help on the civil rights bill and Halleck responded positively. See O'Brien, op. cit., Pp. 144-47. Halleck confirms this account in his Oral Histary Interview for the Kennedy Library, pp. 9-14. 
adversely affect other items of legislation, is more difficult to substantiate. Kennedy's civil rights initiative was presented very near to the end of his Presidency after most of his major legislation had either been passed or defeated and, in any case, it would be almost impossible to isolate such factors in a Congressman's voting behaviour. So any evidence to justify this assumption can only be tentative, but, nevertheless, ought to be considered as a counterbalance to the many criticisms made of Kennedy's leadership in respect of civil rights.

The core of the revisionist critique is that, even considering the near impossibility of getting a bill passed, Kennedy ought to have gone ahead with such legislation to maintain his moral and liberal credibility. Tom Wicker typifies this approach when he writes:

Fighting for a strong civil rights bill, whether it could pass or not, would have done a great deal to shore up the notion of Kennedy as a vigorous liberal and to hold his supporters together in loyalty and enthusiasm. It may be hindsight, but it is nonetheless true that Kennedy's failure to send up a strong civil rights bill was another link in a long chain of cynical or blind American refusals to act either swiftly or adequately in correcting a century of injustice to Negro citizens. ${ }^{25}$

What this type of criticism fails to take into account is the Presidential perspective on civil rights in the context of the legislative programme as a whole. Such an argument is justifiable only if one considers civil rights in a legislative vacuum, but when a President argues that a moral stand on civil rights will damage the chances of other important items in his legislative programme, then the argument assumes a more complex dimension.

One indication that Kennedy may have been correct was an episode that occurred the day after his nationwide radio and television broadcast on civil rights. On i I June 1963 Kennedy publicly outlined the contents of a civil rights bill due to be presented to Congress the following week. The day after the broadcast, the House of Representatives was due to vote an additional authorization for the Area Redevelopment Administration (Kennedy's first major legislative achievement in 196I) and it was expected that the extra money would have been voted without difficulty. In I961 the Area Redevelopment Act was passed in the House by 251-167. In 1963, the day after the civil rights broadcast, the new authorization was defeated by 204-209. An analysis of the two votes reveals that twenty Republicans and nineteen Democrats switched their position from support of the ARA in $196 \mathrm{r}$ to opposition in $1963 .{ }^{26}$ The Republican defections can be explained by genuine partisan differences about the role of the ARA during its two

25 Tom Wicker, IFK and LBJ (New York: William Morrow, I968), p. 89.

26 See Congressional Quarterly Weekly Report, 14 June 1963, p. 951. 
years of existence, but the Democratic defections do appear to be a reaction against the civil rights message. With one exception, all the Democratic defectors were from the southern or border states and, surprisingly, many of them were from states which had been the major beneficiaries of ARA expenditure. For example, Alabama had seventeen ARA projects in hand at the time of the 1963 vote, yet half its delegation switched from support to opposition. Jarman of Oklahoma was another defector, yet Oklahoma had received a larger amount of ARA money than any other state in the union. One must not attach overriding importance to any single vote in the House, but, in the absence of anything more than speculation, this is one of the very few indicators of the validity of Kennedy's claim. The unexpected switch of southern Democratic votes the day after the civil rights broadcast was more than mere coincidence.

The complexity of the Congressional situation facing Kennedy is further highlighted by his non-legislative initiatives in the field of civil rights. The use of the Executive Order is often regarded as a technique for by-passing Congressional opposition, but the history of Kennedy's Executive Order on Housing indicates the inroads Congress made in this area of Presidential prerogative. One should also add that evidence now available reveals that many of the existing accounts of this particular aspect of civil rights policy are simplistic.

Several times during the 1960 election campaign, Kennedy promised to sign an Executive Order ending racial discrimination in federal housing "at the stroke of a pen." In New York, just two days before polling day, he said:

I want to be a President who recognizes every citizen's rights as well as his obligations - particularly when one stroke of the pen on an Executive Order could assure all citizens that every door will be open - in Government employment, in Federal jobs, and to federally financed homes. ${ }^{27}$

That housing Order was a long time coming. Sorensen claims that it was held back in 1961 so as not to offend the two southern sponsors of Kennedy's housing bill, Senator Sparkman and Representative Raines, both of Alabama. ${ }^{28}$ In December $196 \mathrm{I}$ The Wall Street Journal reported that the President had given in to the pressure of southern lawmakers who warned that issuing the Order would endanger the foreign trade bill and other important legislation in the next session. It also quoted Sparkman as saying that the Order would leave lasting resentment and would cost the administration votes. ${ }^{29}$ Twice in 1962 , Kennedy told press conferences that he would

27 See The Speeches of Senator John F. Kennedy, p. 910. 28 Sorensen, Kennedy, p. 480. 29 " Kennedy to Delay Executive Order Barring Discrimination in Federally Aided Housing,"

The Wall Street Journal, 16 Dec. I96r. 
issue the Order when he considered it to be in the public interest. ${ }^{30}$ Sorensen argued that the 1962 delay was attributable to the need for southern support on the bill to create a Housing and Urban Affairs Department, and, when that had been defeated, a further delay was necessary so that the signing of the Order would not be attributed to petty spite. ${ }^{31}$ It was eventually issued on 20 November 1962.

All the revisionist accounts take their cue from Sorensen and explain the delay in signing the housing Order in terms of Kennedy's need to appease the southerners, but, whereas Sorensen sees the whole episode as a demonstration of Kennedy's political skill, the revisionists see it less sympathetically. There is little doubt that the influence of the southerners was important, but new evidence reveals what Sorensen and the revisionists omit in their explanations. The signing of the Order generated a large amount of opposition from a number of northern liberal Democrats in Congress and this was equally responsible for the delay in 1962. This opposition appeared to reach its peak around August of 1962 , just prior to the mid-term Congressional elections. Lee White, Kennedy's staff assistant handling civil rights policy said " there were an awful lot of people running for re-election who let it be known to the White House that, if the President signs that Order, tell him he'd better plan on someone else representing my district besides me." ${ }^{32}$ Documentary evidence at the Kennedy Library shows that among those urging a delay were Senator McNamara of Michigan and Representatives Sullivan of Missouri, Griffiths and Ryan of Michigan and Rogers of Colorado. ${ }^{33}$ On in September Lawrence O'Brien, the Special Assistant for Congressional Relations, reported to Lee White that Leonor Sullivan and Martha Griffiths were "vehement in opposing any Housing Order as they insist it would be devastating in their respective districts." ${ }_{34}$ Griffiths was the most seriously disturbed of all by the possible electoral consequences of Kennedy's proposed action. She represented the ith Congressional district of Michigan which included a surburban area of Detroit and her predicament is revealed in a letter she wrote to Lawrence O'Brien in mid-September. I take the liberty of quoting the letter in full as an illustration of the dilemma in which some northern liberals found themselves

30 See Public Papers of the Presidents 1962 (Washington D.C.: Government Printing Office, 1963), p. 21 and p. 544 .

31 Sorensen, Kennedy, pp. 48I-82.

32 Lee White, interview with author, 21 Aug. 1972

33 See Memorandum from Lawrence O'Brien to Lee White, 15 Scpt. 1962 and Memorandum from Bill Welsh to Lee White, 4 Oct. I962, Lee White Papers (Housing/Executive Order), John F. Kennedy Library.

34 Memorandum from Lawrence O'Brien to Lee White, II Sept. 1962, Lee White Papers (Housing/Executive Order), John F. Kennedy Library. 
on this aspect of civil rights policy and the consequent pressure they exerted on the White House.

Dear Larry:

The Detroit Free Press, as usual, ran a timely and an excellent article in their Sunday issue on Housing Integration. Because I think it presents facts, not fancies, I enclose a copy which I hope you will read. Note - window breaking incident; non-speaking of neighbors; present high vacancy rate; plus support of the local government for integration.

Larry, there is not time enough left before the election for the white areas to understand the full implications of this order; throw the rocks and settle down.

Del Rio, the negro investor, mentioned in this article, has already been in the Redford Township area of my District attempting to buy property. The residents are extremely nervous. Most white people have resigned themselves to the fact of integration, but the suburbs of Detroit believe it will be years before it applies to their exact area. While the Detroit administration and the churches of Detroit are doing their utmost to explain this problem; the suburban areas of my District have Republican administrations. I do not wish to be unfair. It is possible that they would be helpful; but it is not probable.

If such an order is to be issued, it should not be issued immediately preceding an election; because it will be interpreted as political and as an attempt to buy votes.

No Democratic Congressman, from suburbia, to whom I have talked, believes he is in any danger of losing colored votes; but he does feel such an order could cost white votes.

In case the counsel of those seated less close to the fire than I am prevails, however, and I lose this election, would you mind asking the President if I can have the next Supreme Court vacancy, where I can legislate in safety far from the prejudices of the precincts.

\section{Cordially,}

Martha W. Griffiths ${ }^{35}$

While the views of Martha Griffiths, and those others mentioned above, did not represent the position of all northern Democrats from metropolitan districts, they were significant enough to cause Kennedy to delay signing the Executive Order on Housing until after the November elections. The appeasement of southern legislators is only a partial explanation for the delay and the opposition of some northern liberal Democrats made Kennedy's task more complex than is generally recognized.

\section{III}

Kennedy's general leadership qualities are frequently criticized by the revisionists when discussing civil rights. Two examples will suffice:

Kennedy and his aides were ill-equipped by their pragmatist background and

35 Letter from Martha Griffiths to Lawrence O'Brien, 18 Sept. 1962, Lee White Papers (Housing/Executive Order), John F. Kennedy Library. 
bias, for coping with a social movement generated out of injustice and striving for a vision of community. Adept at calculating the arithmetic of existing political forces, they had great trouble understanding a struggle which, at its heart, called into question those forces and indicated the need for a new form of politics. $^{36}$

In the end, then, Kennedy's attitude compromised his promise to be an assertive executive who would be willing to serve the people even at the risk of incurring their momentary displeasure. Too often - particularly when an important issue was controversial - Kennedy was reluctant to address the issue in a major speech. Too often he was content to wait for a change in circumstance rather than to try to create a public receptivity or tolerance for a particular policy or program. Civil rights and Vietnam are two examples. ${ }^{37}$

Like Wicker, both imply that a wider concept of Presidential leadership is necessary to overcome Congressional obstructions. They assume that the road to success requires Presidents to embark on a public education crusade which would generate support in the nation at large which Congress would then inevitably reflect. The model they have in mind, of course, is the New Deal Presidency of Franklin Roosevelt. Kennedy's failure is his inability to ape the Roosevelt style and this type of criticism is reflected in the last few lines of Henry Fairlie's attack on Kennedy and his times when he writes:

A people can be nourished to believe that there are necessary things to be done, which they have overlooked, and that they have the necessary capacity to do them. That was the art practised by Franklin Roosevelt, the greatest political leader of this century and an American beyond any dispute. ${ }^{38}$

This line of criticism fails to recognize that Kennedy was not occupying the White House during a period of domestic crisis with a large ideological majority in Congress. Genuine crises or massive party majorities or both afford the President great power over Congress, but, in normal conditions, Presidents are not above the political processes of persuasion and bargaining. Special interests do not stand aside in favour of a national interest. In the absence of war or depression or some other genuine emergency, Presidential power and authority are much more limited. It is fallacious to suppose that the Roosevelt "fireside-chat" style of leadership is the way to generate public support for Presidential policies in all circumstances. The sense of urgency that accompanied the New Deal was missing from the New Frontier and that made the public appeal over the heads of Congress a much less viable tool of Presidential leadership. Kennedy did once attempt this technique in support of his medicare legislation, but it had no effect apart from upsetting key Congressmen. In the absence of an overriding crisis, the

36 Miroff, p. 269.

37 Paper, p. 242.

38 Fairlie, p. $3^{64}$.

AM.ST. -2 
dimensions of Presidential-Congressional relations are very different from the Roosevelt experience, and a President like Kennedy needed more than publicity techniques to overcome the inherent conflict and frictions within the American political system. There seems to be little value in judging Kennedy's leadership by inappropriate standards and within inapplicable frameworks. Kennedy had neither the crisis nor the Congressional majority to help him. He was elected by a narrow margin of votes without any clear mandate for his programme and his position illustrated the realistic limitations of Presidential leadership under normal conditions.

On civil rights, Kennedy's task was to overcome a complex pattern of opposition to a moderate and pragmatic civil rights programme. The conflict was not simply one of ideas and attitudes amenable to change. It was a deep-rooted, systemic conflict in which Kennedy had a share of the power, but the approval of the civil rights bill by the House Judiciary Committee on 20 November 1963 indicated more than a measure of leadership skill. ${ }^{39}$ The framework of the revisionist critique tends to distort the record. It is argued here that Kennedy did not promise as much as some claim he did; that it would be fairer to judge his performance against those commitments that he actually made; that his assumptions about Congressional reaction to civil rights legislation seem to have been correct and that inappropriate notions of Presidential leadership are not the most fruitful basis for historical analysis.

39 The Bill was eventually passed the following year in the wake of Kennedy's assassination. President Johnson also signed a Voting Rights Act in 1965 passed by the massive Democratic majorities of the 89 th Congress. 